\title{
Analisis Pemanfaatan Media Daring dalam Pembelajaran Matematika Ditinjau dari Kemandirian Belajar Siswa di Kelas XI SMAN 1 Koto Balingka
}

\author{
Armiati $^{1)}$, Yanrizawati $^{2)}$ \\ ${ }^{1)}$ Jurusan Matematika, FMIPA Universitas Negeri Padang \\ ${ }^{2)}$ Guru Matematika SMAN 1 Balingka \\ armiati@fmipa.unp.ac.id ${ }^{1)}$, yanrizawati82@gmail.co ${ }^{2)}$
}

\begin{abstract}
Covid pandemic 19 has had a huge impact on education. Large-scale social restrictions make learning only possible at home. Teachers must have alternative means so that learning can be carried out so that learning objectives can be achieved properly. One of the learning media that can be used is learning media through the internet network (online). Online media that can be used include whatsapp, google classroom, zoom, etc. The purpose of this study is to see whether learning through online media can be carried out well in class XI of SMAN 1 Koto Balingka. This research is a descriptive study, literature study and survey method through the analysis of learning documents such as assignments and achievement of students carrying out the tasks given through whatsapp online media. The results of this study are through analysis it can be seen that learning conducted through online is less well implemented because of the internet network constraints where students live less well and burdened students with internet quotas and the still presence of students do not yet have the means for online learning.
\end{abstract}

Keywords : Online media, Covid Pandemic 19, Learning Independence

This is an open access article distributed under the Creative Commons 4.0 Attribution License, which permits unrestricted use, distribution, and reproduction in any medium, provided the original work is properly cited. $\odot 2018$ by author and Universitas Negeri Padang.

\section{PENDAHULUAN}

Pandemi Corona Virus Disease 2019 (Co vid 19) terjadi pertama kalinya di Wuhan China. Virus ini terus menyebar ke belahan negara lain termasuk Indonesia. Berbagai upaya telah dila kukan pemerintah masing-masing negara untuk mencegah penyebaran virus ini. Salah satu upa ya yang dilakukan pemerintah Indonesia adalah dengan menerapkan PSBB (Pembatasan Sosial Berskala Besar). Di Sumatera Barat PSBB di mulai pada tanggal 22 April dan berakhir pada tanggal 8 Juni 2020. Hal ini tentu sangat ber dampak bagi kehidupan masyarakat terutama di bidang ekonomi dan pendidikan. Akibat pande mi covid 19 ini telah terjadi berbagai perubahan dalam kehidupan masyarakat.

Surat Edaran Mendikbud Nomor 36962/ MPK.A/HK/2020 yang dikutip oleh Charismia dji (2020) dan Pranawati (2020) menyebutkan bahwa seluruh kegiatan belajar mengajar baik di sekolah maupun kampus perguruan tinggi meng gunakan daring (dalam jaringan) sebagai upaya pencegahan terhadap perkembangan dan penye baran Coronavirus disease (Covid-19). Sejalan dengan surat edaran Kemendikbud No. 36962/ MPK.A/HK/2020, Tafqihan (Radita, 2018) me nyebutkan bahwa pembelajaran dalam jaringan dapat digunakan sebagai alternatif ketika kegiat an pembelajaran tidak dapat dilaksanakan seba gaimana mestinya.

Pada saat ini pembelajaran menerapkan prinsip pembelajaran modern. Model pembela jaran modern (Charismiadji, 2020) sudah diatur dalam Permendikbud no. 22 tahun 2016 tentang Standar Proses dengan prinsip yang menjadikan guru sebagai fasilitator pembelajaran yang mam pu membelajarkan siswa. Guru bukanlah satusatunya sumber belajar, tetapi guru hendaklah mampu menjadi lingkungan sekitar siswa seba gai sumber belajar, pembelajaran kontekstual. Guru dituntut untuk mampu mengembangkan se gala potensi yang ada dalam diri siswa, mem perhatikan keberagaman siswa. Selain itu guru dituntut mampu memanfaatkan teknologi dalam pembelajarannya.

Menurut Direktorat Jenderal Guru dan Te naga Kependidikan (Ditjen GTK) (Sobri, Nur saptini, Novitasari, 2020) pembelajaran berbasis daring merupakan pemanfaatan jaringan internet oleh siswa dalam proses pembelajaran. Pendekat an pembelajaran berbasis daring memiliki karak teristik sebagai berikut 1) menuntut pembelajar untuk membangun dan menciptakan pengetahu an secara mandiri (constructivism); 2) pembela jar akan berkolaborasi dengan pembelajar lain dalam membangun pengetahuannya dan meme 
cahkan masalah secara bersama-sama (social constructivism); 3) membentuk suatu komunitas pembelajar (community of learners) yang in klusif; 4) memanfaatkan media laman (website) yang bisa diakses melalui internet, pembelajaran berbasis komputer, kelas virtual, dan atau kelas digital; 5) interaktivitas, kemandirian, aksesi bilitas, dan pengayaan (Ditjen GTK 2016, p.5). Beberapa prinsip yang menjadi landasan dalam pelaksanaan pembelajaran berbasis daring ( $\mathrm{Sob}$ ri, Nursaptini, Novitasari, 2020) yaitu sebagai berikut: a) rumusan tujuan pembelajaran pada setiap modul telah jelas, spesifik, teramati, dan terukur untuk mengubah perilaku pembelajar; b) konten di modul telah relevan dengan kebutuhan pembelajar, masyarakat, dunia kerja, atau dunia pendidikan; c) meningkatkan mutu pendidikan yang ditandai dengan pembelajaran lebih aktif dan mutu lulusan yang lebih produktif; d) efisien si biaya, tenaga, sumber dan waktu, serta efek tivitas program; e) pemerataan dan perluasan ke sempatan belajar; f) pembelajaran yang berkesi nambungan dan terus menerus.

Menurut Kuntarto (2017) manfaat positif pembelajaran berbasis daring antara lain: (1) sa ngat efektif digunakan dalam kegiatan pembela jaran; (2) model pembelajaran telah mampu me ningkatkan penyerapan mahasiswa terhadap ma teri pembelajaran, dibandingkan dengan hanya menggunakan model pembelajaran tatap muka; (3) memberikan sebuah pengalaman baru yang lebih menantang dari pada model pembelajaran konvensional atau tatap muka. Pembelajaran Ma tematika (Kurniawan \& Marliani, 2014) melalui web (daring) akan mempunyai kelebihan yang dapat memberikan fleksibilitas, interaktivitas, ke cepatan dan visualisasi dalam proses pembela jaran.

Kemandirian menurut Bernadib (Isnaniah, 2017) meliputi perilaku mampu berinisiatif, mampu mengatasi hambatan/masalah, mempu nyai rasa percaya diri dan dapat melakukan sesuatu sendiri tanpa bantuan orang lain. Me nurut Darr dan Fisher (Izzati, 2017) seorang siswa mandiri adalah seorang yang aktif terlibat dalam memaksimalkan kesempatan dan kemam puan untuk belajar.

Kemandirian belajar siswa, menurut $\mathrm{Ta}$ har dan Enceng yang dikutip oleh Huda dkk (2019), adalah aktivitas belajar yang dilakukan individu dengan kebebasannya dalam menentu kan dan mengelola sendiri bahan ajar, waktu, tempat dan memanfaatkan berbagai sumber bela jar yang diperlukan. Sedangkan menurut Proyek ti (Arisinta, As'ari, dan Sa'dijah, 2019) keman dirian belajar adalah suatu kegiatan yang mam pu dalam menyelesaikan masalahnya sendiri dan memiliki kepercayaaan diri tanpa bantuan orang lain.

Menurut Lilik dkk (Putra, 2019) kemandi rian belajar merupakan suatu keterampilan da lam belajar yang dalam proses belajar individu didorong, dikendalikan dan dinilai oleh individu itu sendiri. Sedangkan menurut Kozma, Belle dan William (Sutama, Hartini, Novitasati, dan Meggy, 2019) kemandirian belajar merupakan bentuk belajar yang memberikan kesempatan ke pada pembelajar untuk menentukan tujuan, sum ber dan kegiatan belajar sesuai dengan kebu tuhan sendiri.

Adapun karakteristik belajar menurut $\mathrm{Su}$ marno yang dikutip oleh Sukmawati, Yenni (2020) antara lain: 1). Menganalisis kebutuhan belajar matematika dengan cara merumuskan tujuan dan strategi belajar; 2). Memilih dan menerapkan strategi belajar; 3). Memantau dan mengevaluasi diri, apakah strategi telah dilaksa nakan dengan benar, memeriksa hasil (proses dan produk) serta merefleksi diri untuk mem peroleh umpan balik.

Berbagai upaya dilakukan guru agar pem belajaran melalui daring dapat berjalan sebagai mana mestinya. Sehubungan dengan pemilihan media pembelajaran Rahmi, Armiati, dan Syari fuddin menyebutkan bahwa "Learning media as a tool of learn that clarify the presentation of information in learning process". Kutipan ini menjelaskan bahwa media pembelajaran sebagai alat belajar yang dapat memperjelas penyajian informasi dalam proses pembelajaran. Gagne (Imania \& Bariah, 2019) mengatakan bahwa me dia adalah berbagai jenis komponen dalam ling kungan siswa yang dapat merangsang siswa untuk belajar. Menurut Sefriyanti (2019) media pembelajaran matematika adalah alat atau media yang membawa pesan-pesan dan informasi pembelajaran matematika dari pemberi pesan kepada penerima pesan yang disampaikan secara sistematis sehingga penerima pesan memperoleh pengetahuan dan keterampilan sesuai tujuan pembelajaran.

Selama masa pandemi covid 19 media on line yang digunakan sebagai sarana penyampai an pembelajaran dapat berbentuk video pembela jaran online, aplikasi whatsapp, zoom dll. Pada penelitian ini penulis hanya menggunakan media yang sudah dimiliki oleh siswa yaitu media whatsapp. Hal ini disebabkan pada umumnya 
media whatsapp merupakan media komunikasi yang sudah dimiliki oleh masyarakat. Peneliti berharap dengan menggunakan aplikasi whats app siswa merasa tidak terbebani melaksanakan pembelajaran. Langkah awal yang dilakukan ada lah membuat grup whatsapp yang beranggota kan guru dan siswa dalam satu kelas guna untuk mendiskusikan materi pembelajaran dan pembe rian tugas. Penelitian ini dilakukan untuk 7 kali pertemuan. Setiap pertemuan siswa diminta ber diskusi tentang materi pembelajaran dan mena nyakan materi yang kurang dimengerti oleh sis wa di media grup whatsapp.

Armiati, Yerizon, dan Niscaya (2018) me nyatakan "The learning takes advantage of a technology, such as instructional videos aimed at helping students to learn outside the class room”. Kutipan ini menjelaskan bahwa pembela jaran dengan memanfaatkan teknologi dapat membantu siswa belajar di luar kelas. Untuk itu guna menunjang proses pembelajaran guru mere komendasikan video youtube kepada siswa un tuk membantu siswa memahami materi pembela jaran, antara lain cannel bimbel SMARRT ten tang polinomial. Di akhir pembelajaran guru memberikan tugas. Tugas yang diberikan kemu dian difotokan siswa dan dikirim melalui ja ringan pribadi kepada guru dengan batas limit waktu tertentu. Kemudian guru memeriksa apa kah setiap siswa telah mengirimkan tugasnya. Kemudian menganalisis siswa yang belum me ngirimkan tugas dan menanyakan kesulitan yang dihadapi mereka.

Melalui penelitian ini permasalahan yang dijawab adalah 1) Bagaimanakah kemandirian belajar siswa di SMAN 1 Koto Balingka selama masa pandemi covid 19?, dan 2) Apakah ken dala yang dihadapi siswa di SMAN 1 Koto Ba lingka selama pembelajaran daring masa pan demi covid 19 ?

\section{METODE PENELITIAN}

Penelitian ini merupakan penelitian desk riptif. Tujuan penelitian ini adalah untuk melihat kemandirian belajar siswa SMAN 1 Koto Baling ka selama pembelajaran daring masa pandemi covid 19 dan untuk mengetahui kendala yang di hadapi oleh siswa selama pembelajaran daring.

Untuk mencapai tujuan penelitian instru men yang digunakan untuk melihat kemandi rian siswa adalah dokumen tugas siswa dan ang ket terbuka tentang kendala yang dihadapi oleh siswa selama pembelajaran daring. Dokumen tu gas siswa dianalisis untuk melihat kemandirian belajar siswa. Siswa dikatakan mandiri belajar apabila minimal 50\% dari jumlah siswa me ngumpulkan tugas sedangkan untuk melihat ken dala yang dihadapi siswa dianalisis dengan teknik statistika deskriptif untuk memudahkan penyajian informasi. Adapun subjek penelitian ini adalah siswa kelas XI IPA 1 SMAN 1 Koto Balingka yang berjumlah 27 orang.

\section{HASIL DAN PEMBAHASAN}

\section{Kemandirian belajar siswa di SMAN 1 Koto Balingka selama pembelajaran daring masa pandemi covid 19}

Untuk memahami kemandirian belajar sis wa, dilakukan pengamatan terhadap pengerjaan tugas yang diberikan. Pengamatan dilakukan ter kait waktu pengumpulan tugas yang dibagi ke dalam beberapa point, yaitu tepat waktu, terlam bat tetapi pada hari yang sama, terlambat satu hari, atau tidak mengumpulkan tugas. Berdasar kan analisis dokumen pengumpulan tugas siswa, diperoleh hasil yang disajikan dalam Tabel 1 .

Berdasarkan Tabel 1 dapat diketahui bah wa pada pertemuan pertama hanya $22 \%$ saja sis wa yang mengumpulkan tugas tepat waktu, $44 \%$ siswa terlambat mengumpulkan tugas akan teta pi masih dalam hari yang sama, $11 \%$ siswa me ngumpulkan tugas keesokan harinya dan $22 \%$ siswa tidak mengumpulkan tugas.

Tabel 1. Distribusi pengumpulan tugas berdasarkan waktu penyerahan

\begin{tabular}{|c|l|l|l|l|}
\hline $\begin{array}{c}\text { Perte } \\
\text { muan } \\
\text { ke- }\end{array}$ & $\begin{array}{c}\text { Tugas } \\
\text { tepat } \\
\text { waktu }\end{array}$ & $\begin{array}{l}\text { Terlam } \\
\text { bat (hari } \\
\text { yang } \\
\text { sama) }\end{array}$ & $\begin{array}{l}\text { Terlam } \\
\text { bat esok } \\
\text { hari }\end{array}$ & $\begin{array}{c}\text { Tidak } \\
\text { memberi } \\
\text { kan tugas }\end{array}$ \\
\hline $\mathbf{1}$ & $\begin{array}{l}6 \text { orang } \\
(22 \%)\end{array}$ & $\begin{array}{l}12 \text { orang } \\
(44 \%)\end{array}$ & $\begin{array}{l}3 \text { orang } \\
(11 \%)\end{array}$ & $\begin{array}{l}6 \text { orang } \\
(22 \%)\end{array}$ \\
\hline $\mathbf{2}$ & $\begin{array}{l}12 \text { orang } \\
(44 \%)\end{array}$ & $\begin{array}{l}5 \text { orang } \\
(19 \%)\end{array}$ & $\begin{array}{l}4 \text { orang } \\
(15 \%)\end{array}$ & $\begin{array}{l}6 \text { orang } \\
(22 \%)\end{array}$ \\
\hline $\mathbf{3}$ & $\begin{array}{l}15 \text { orang } \\
(55 \%)\end{array}$ & $\begin{array}{l}2 \text { orang } \\
(7 \%)\end{array}$ & $\begin{array}{l}2 \text { orang } \\
(7 \%)\end{array}$ & $\begin{array}{l}8 \text { orang } \\
(30 \%)\end{array}$ \\
\hline $\mathbf{4}$ & $\begin{array}{l}6 \text { orang } \\
(22 \%)\end{array}$ & $\begin{array}{l}9 \text { orang } \\
(33 \%)\end{array}$ & $\begin{array}{l}4 \text { orang } \\
(15 \%)\end{array}$ & $\begin{array}{l}8 \text { orang } \\
(30 \%)\end{array}$ \\
\hline $\mathbf{5}$ & $\begin{array}{l}5 \text { orang } \\
(19 \%)\end{array}$ & $\begin{array}{l}12 \text { orang } \\
(44 \%)\end{array}$ & $\begin{array}{l}2 \text { orang } \\
(7 \%)\end{array}$ & $\begin{array}{l}8 \text { orang } \\
(30 \%)\end{array}$ \\
\hline $\mathbf{6}$ & $\begin{array}{l}16 \text { orang } \\
(59 \%)\end{array}$ & $\begin{array}{l}1 \text { orang } \\
(4 \%)\end{array}$ & $\begin{array}{l}2 \text { orang } \\
(7 \%)\end{array}$ & $\begin{array}{l}8 \text { orang } \\
(30 \%)\end{array}$ \\
\hline $\mathbf{7}$ & $\begin{array}{l}4 \text { orang } \\
(15 \%)\end{array}$ & $\begin{array}{l}5 \text { orang } \\
(19 \%)\end{array}$ & $\begin{array}{l}7 \text { orang } \\
(26 \%)\end{array}$ & $\begin{array}{l}11 \text { orang } \\
(41 \%)\end{array}$ \\
\hline
\end{tabular}

Pada pertemuan ke dua persentase siswa yang mengumpulkan tugas tepat waktu bertam bah menjadi $44 \%$, $19 \%$ siswa terlambat tetapi masih dihari yang sama dan $15 \%$ siswa mengum pulkan tugas keesokan harinya serta $22 \%$ siswa tidak mengumpulkan tugas sama sekali. Pada 
pertemuan kedua terdapat penambahan siswa yang mandiri dalam belajar, hal ini dapat dilihat dari naiknya persentase siswa yang mengumpul kan tugas tepat waktu.

Pada pertemuan ketiga 55\% siswa yang mengumpulkan tugas tepat waktu, 7\% siswa yang terlambat mengmpulkan tugas tetapi masih di hari yang sama, 7\% siswa yang mengumpul kan tugas kesokan harinya dan 30\% siswa yang tidak mengumpulkan tugas. Pada pertemuan keti ga terjadi kenaikan persentase siswa yang me ngumpulkan tugas tepat waktu sehingga dapat disimpulkan bahwa lebih banyak siswa yang mandiri dalam belajar dibandingkan pertemuan sebelumnya.

Pada pertemuan keempat siswa yang me ngumpulkan tugas tepat waktu hanya $22 \%$ dan $9 \%$ terlambat tetapi masih dalam hari yang sama serta $15 \%$ siswa mengumpulkan tugas kesokan harinya dan 30\% siswa tidak mengumpulkan tu gas. Pada pertemuan keempat terjadi penurunan jumlah siswa yang mandiri dalam belajar, hal ini dapat dilihat dari menurunnya persentase siswa yang mengumpulkan tugas tepat waktu. Siswa mengumpulkan tugas keesokan harinya. Terjadi nya penurunan persentase siswa yang mengum pulkan tugas disebabkan karena matinya aliran listrik di daerah utara Pasaman Barat. Hal ini me nyebabkan susahnya jaringan internet di daerah tempat siswa berdomisili, sehingga siswa terlam bat mengumpulkan tugas.

Sedangkan pada pertemuan kelima persen tase siswa yang mengumpulkan tugas tepat wak tu sebesar 19\%, 44\% siswa terlambat tetapi ma sih pada hari yang sama, $7 \%$ siswa mengumpul kan tugas keesokan harinya dan 30\% siswa tidak mengumpulkan tugas. Pada pertemuan kelima ini kembali terjadi penurunan persentase siswa yang mengumpulkan tugas tepat waktu. Persenta se siswa yang tidak mengumpulkan tugas menga lami kenaikan. Hal ini disebabkan banyaknya siswa yang terkendala mengumpulkan tugas dikarenakan harus membantu pekerjaan orang tua, ada yang pergi ziarah dan ada yang mengikuti orangtua ke pabrik yang letaknya cukup jauh dari tempat siswa berdomisili dimana jaringan telekomunikasi yang tidak ada. Hal ini terjadi karena orangtua beranggapan bahwasanya anaknya sedang libur sekolah sehingga dapat membantu pekerjaannya. Guru kembali mengingatkan siswa bahwa ketiadaan siswa di sekolah bukan berarti siswa di liburkan akan tetapi siswa belajar di rumah dan diharapkan siswa dapat membagi waktu antara membantu orangtua dengan tugas belajar yang diberikan guru.

Pada pertemuan keenam persentase siswa yang mengumpulkan tugas tepat waktu sebesar $59 \%$, yang terlambat tetapi pada hari yang sama sebesar $4 \%$, sedangkan persentase siswa yang mengumpulkan tugas keesokan harinya sebesar $7 \%$ sedangkan $30 \%$ siswa tidak mengumpulkan tugas. Pada pertemuan ini terjadi kenaikan per sentase siswa yang mengumpulkan tugas tepat waktu, sehingga dapat dikatakan bahwa lebih da ri 50\% siswa sudah mandiri dalam belajar.

Pada pertemuan ketujuh $15 \%$ siswa me ngumpulkan tugas tepat waktu, $19 \%$ siswa ter lambat tetapi pada hari yang sama, dan $26 \%$ sis wa mengumpulkan tugas keesokan harinya serta $41 \%$ siswa tidak mengumpulkan tugas. Pada per temuan ketujuh terjadi lagi penurunan persenta se siswa yang mengumpulkan tugas tepat waktu dan persentase siswa yang tidak mengumpulkan tugas mengalami kenaikan. Seperti pada perte muan kelima pada pertemuan ketujuh siswa yang mengumpulkan tugas kembali mengalami penurunan, hal ini terjadi karena pemadaman listrik kembali terjadi di daerah Pasaman Barat bagian utara dan siswa yang membantu orangtua ke kebun. Siswa beralasan kebun yang mereka datangi jauh dari tempat mereka berdomisili dan tidak adanya sinyal di daerah tersebut. Alasan lain yang diberikan siswa adalah adanya keje nuhan siswa belajar di rumah, hal ini mengaki batkan lalainya mereka mengerjakan tugas yang diberikan oleh guru.

Berdasarkan data di atas terlihat bahwa ra ta-rata $31,57 \%$ siswa yang mengumpulkan tugas tepat waktu, $6,57 \%$ siswa terlambat mengumpul kan tugas tetapi masih dalam hari yang sama, $3,43 \%$ siswa mengumpulkan tugas esok harinya dan 29,29\% siswa tidak mengumpulkan tugas. Jika dikaitkan dengan pengertian kemandirian belajar menurut Darr dan Fisher (Izzati,2017) maka dapat disimpulkan bahwa secara rata-rata terdapat $31,57 \%$ siswa yang telah mandiri dalam belajar karena mereka mampu memaksimalkan kesempatan dan kemampuan sehingga dapat me nyerahkan tugas tepat waktu sedangkan siswa yang lainnya masih perlu meningkatkan kemam puannya agar di masa yang akan datang dapat lebih mandiri dalam belajar. Dari data yang diperoleh terdapat beberapa siswa yang selalu mengumpulkan tugas tepat waktu, setelah dite liti mereka merupakan siswa yang tinggal di dae rah yang memiliki jaringan internet bagus dan merupakan siswa yang memiliki kemampuan 
tinggi di kelasnya. Namun terjadi fluktuasi pada setiap pertemuan.

Ketika siswa kembali sekolah tatap muka di akhir semester guru kembali mengingatkan siswa tentang tugas yang belum dikumpulkan de ngan memberi sanksi jika siswa tidak mengum pulkan tugas maka pemberian nilai mereka akan ditunda. Hal ini menjadikan siswa segera me lengkapi tugasnya. Di akhir pembelajaran siswa diberikan angket terbuka untuk mengetahui ken dala-kendala yang dihadapi siswa selama pem belajaran.

\section{Kendala yang dihadapi siswa di SMAN 1 Koto Balingka selama pembelajaran daring masa pandemi covid 19}

Setelah dilakukan pemberian angket terbu ka kepada 27 orang siswa mengenai tanggapan siswa terhadap pembelajaran daring dan kenda la-kendala apa saja yang mereka hadapi dipero leh hasil bahwa pembelajaran melalui daring da pat meningkatkan kemandirian belajar dari sis wa, hal ini dapat dilihat dari adanya kenaikan persentase siswa yang memberikan tugas tepat waktu dan dari wawancara siswa melalui angket terbuka yang diberikan oleh guru. Dari angket yang diberikan dapat dilihat bahwa siswa lebih kreatif mencari sumber belajar lain apabila ring kasan materi yang diberikan oleh guru kurang dipahami. Rata-rata siswa merasa tertantang de ngan pembelajaran online. Siswa lebih kreatif menemukan sumber belajarnya sendiri agar ma teri yang diberikan oleh guru dapat mereka pa hami. Hal ini sejalan dengan penelitian Ali sadikin (2020) bahwa pembelajaran daring dapat membantu siswa belajar mandiri dan dapat me ningkatkan motivasi siswa.

Setelah dilakukan wawancara dengan sis wa terkait adanya keterlambatan mengumpulkan tugas ada beberapa kendala yang dihadapi oleh siswa antara lain: 1). sukarnya jaringan internet di tempat domisili siswa; 2). Siswa tidak memi liki kuota internet; 3) Daerah tempat siswa berdo misili menyebar sehingga menyulitkan siswa mengunjungi temannya untuk bertanya tentang tugas yang diberikan oleh guru; 4) siswa ikut membantu orangtua bekerja di kebun sehingga terlambat mengerjakan dan mengumpulkan tu gas; 5) Adanya siswa yang tidak memiliki smart phone dan tempat domisili siswa tersebut yang jauh dari teman sekelasnya menyebabkan keter lambatan siswa mendapat informasi tentang tu gas yang diberikan oleh guru; 6) adanya siswa yang baru memiliki aplikasi whattapp setelah be berapa kali pembelajaran dilakukan; 7) adanya kejenuhan siswa mengerjakan tugas yang dibe rikan oleh guru mengingat setiap mata pelajaran ada tugas yang harus mereka kerjakan.

Kendala-kendala yang dialami oleh siswa ini sejalan dengan kendala-kendala yang ditemu kan (Rahman, 2020) selama pembelajaran da ring yaitu: 1) tidak memiliki Handphone; 2) me miliki Handphone tetapi masih jadul; 3) memi liki Handphone tetapi tidak punya kuota; 4) ja ringan internet bermasalah; 5) aliran listrik se ring putus.

\section{KESIMPULAN}

Berdasarkan hasil penelitian dapat disim pulkan bahwa pembelajaran daring di SMAN 1 Koto Balingka dapat meningkatkan kemandirian siswa akan tetapi masih terdapat kendala dalam pelaksanaannya antara lain disebabkan oleh ke terbatasan jaringan internet di daerah tempat sis wa berdomisili dan terbebaninya siswa dengan kuota internet yang memberatkan. Karena pene litian ini hanya untuk media daring yang meng gunakan aplikasi whatsapp dengan asumsi bah wa aplikasi ini sudah dimiliki oleh siswa sehing ga diperoleh kesimpulan bahwasanya untuk me dia yang sederhana saja pembelajaran di SMAN 1 Koto Balingka masih terkendala apalagi jika menggunakan aplikasi yang membutuhkan kua litas jaringan internet yang lebih tinggi. Saran bagi peneliti berikutnya adalah agar dapat mem buat bahan ajar yang dapat membantu siswa menghadapi pembelajaran online tanpa harus terikat dengan kualitas jaringan internet sehing ga tujuan pembelajaran dapat tercapai.

\section{DAFTAR PUSTAKA}

Arisinta, R., As'ari, A R., \& Sa'dijah, C. (2019). Rrealistic Mathematics Education untuk Meningkatkan Kemandirian Belajar Ma tematika. jurnal UM, Volume 4 No.6 Hal 738-746.

Armiati, Yerizon, \& Niscaya, R. (2019). Flipped classroom based mathematics learning equipment for students in grade X SMA. ICOMSET2018, Conference Series2019.

Charismiadji, I. (2020, April 1). News.destik. com. Dipetik Maret 2020, dari https:// news.detik.com/kolom/d-4960969/me ngelola-pembelajaran-daring-yang-efe ktif 
Huda, M N., Mulyono, Rosyidac, I., \& Wardo no. (2019). Kemandirian Belajar Berban tuan Mobile Learning. PRISMA 2: Prosi ding Seminar Nasional Matematika, http://journal.unnes.ac.id/sju/index.php/ prisma/.

Ika. (2020, Juni 13). www.ugm.ac.id. Dipetik Juni 2020, dari https://ugm.ac.id/id/beri ta/19552-membedah-tantangan-pembela jaran-daring-di-tengah-pandemi-covid19

Imania, K A N \& Bariah, S K. (2019). Ran cangan Pengembangan Instrumen Peni laian Pembelajaran Berbasis Daring. PETIK, Vol. 5 No. 1 .

Isnaniah. (2017). Peningkatkan Kreativitas dan Kemandirian Belajar Mahasiswa Mela lui Model Pembelajaran Berbasis Pro yek Pada Perkuliahan Media Pembela jaran Matematika. SUSKA, Vol.3 No. 2 Hal 83-91.

Izzati, N. (2017). Penerapan Pmr pada Pembela jaran Matematika untuk Meningkatkan kemandirian Belajar Siswa SMP. Jurnal Kiprah, Vol. 5 No. 2.

Kuntarto, E. (2017). Keefektifan Model Pem belajaran Daring Dalam Perkuliahan Ba hasa Indonesia Di Perguruan Tinggi. Journal Indonesian Language Educa tion and Literature, Vol. 3 No. 1.

Kurniawan, D T., Marliani, L. (2014). Pembela jaran Matematika Konsep Aljabar Terha dap Siswa Kelas VII SLTP Melalui Website Interaktif. $\delta E L T \Delta$, Vol.2 No. 1 Hal 89-94.

Pranawati, R. (2020, April 29). Jawapos.com. Dipetik Juni 2020, dari https://www. jawapos.com/opini/29/04/2020/pembela jaran-daring-untuk-siswa/

Putra, D P W. (2019). Pembelajaran Matematika dengan Pendekatan Self-Regulated Le arning untuk Membangun Kemandirian Belajar Siswa. Square : Journal of Ma thematics and Mathematics Education, Vol. 1 Hal 49.

Radita, N. (2018). Pengembangan Sistem Pem belajaran dalam Jaringan pada Materi Teori Grafik. MUST, Vol.3 No. 1 Hal 33-45.

Rahman, E F. (2020, Mei). kompasiana. Dipetik Oktober 2020, dari https://www.kom pasiana.com/

Rahmi, A., Armiati, \& Syarifuddin, H. (2018). Mathematics learning media develop ment of based computer on translation context in senior high school. Pro ceeding INCESST.

Sadikin, A. dkk. (2020). Pembelajaran Daring di Tengah Wabah Covid 19. BIODIK, Vol 6 No. 2.

Sefrianti, D. (2019). Pengembangan Media Pem belajaran Materi Dimensi 2 Dan 3 Berba sis Aplikasi Wingeom Di Smkn 3 Sijun jung. Jurnal Saintika Unpam : Jurnal Sains dan Matematika Unpam, Vol. 2 Hal 124.

Sobri, M., Nursaptini, \& Novitasari, S. (2020). Mewujudkan Kemandirian Belajar Mela lui Pembelajaran Berbasis Daring di Perguruan Tinggi pada Era Industri 4.0. Jurnal Pendidikan Glasser, Vol. 4 No.1.

Sukmawati, R., Yenni. (2020). Penggunaan Lem bar Aktivitas Siswa Pada Pembelajaran Matematika Smp Dalam Meningkatkan Kemandirian Belajar Siswa. SIGMA, Vol.5 No. 2 Hal 57-64.

Sutama, Hartini, S., Novitasati, S., \& Meggy. (2019). Kemandirian dalam Pembela jaran Matematika di Madrasah Tsana wiyah. Jurnal VARIDIKA, Vol. $30 \mathrm{Hal}$. 7-14. 